\title{
ASSESSMENT OF THE DEMOGRAPHIC SITUATION OF UKRAINE: NATURAL MOVEMENT AND POPULATION REPRODUCTION
}

\section{ОЦІНКА ДЕМОГРАФІЧНОЇ СИТУАЦІЇ УКРАЇНИ: ПРИРОДНИЙ РУХ ТА ВІДТВОРЕННЯ НАСЕЛЕННЯ}

\section{Hanna Svydlo ${ }^{1}$ \\ Iryna Sierova ${ }^{2}$}

DOI: https://doi.org/10.30525/978-9934-26-001-8-2-5

Abstract. Due to the difficult socio-economic situation and worsening of demographic situation, including the consequences of hostilities and ongoing occupation of the part of Ukraine, today the importance of population study and the research on the factors influencing its changes is increasing. During the study of demographic processes on the basis of a thorough analysis, strategic decisions relevant to the use and reproduction of the country's labour potential, stimulation of the birth rate, reduction of mortality, increase of natural population growth, prevention of depopulation processes, providing effective employment and improvement of social protection of the people are made.

The demographic factor is one of the determinants for ensuring sustainable and safe development of the country, and the issue of demographic development should be considered as a factor and at the same time as a result of the functioning of the state.

The main purpose of the study is to identify trends in the changes of the main indicators characterizing demographic processes in the country.

Methodologically and informationally, this paper is based on the scientific works, the materials from reccurent publications and Internet, the laws and regulations and the data of the State Statistics Service of Ukraine and Ptoukha Institute for Demography and Social Studies of the National

\footnotetext{
${ }^{1}$ Associate Professor of the Department of Statistics and Economic Forecasting, Simon Kuznets Kharkiv National University of Economics, Ukraine

${ }^{2}$ Associate Professor of the Department of Statistics and Economic Forecast-ing, Simon Kuznets Kharkiv National University of Economics, Ukraine
} 
Academy of Sciences of Ukraine. The methods used in the study are structural and dynamic analysis, comparison and generalization of the data collected by the State Statistics Service of Ukraine and Ptoukha Institute for Demography and Social Studies of the National Academy of Sciences of Ukraine.

During a study of a phenomenon or a process, first of all, the categorical apparatus is determined. Based on the purpose of the study, the concept of reproduction and natural movement of the population is defined and their theoretical description is given.

This paper considers the reproduction of the population as the historically and socio-economically conditioned process of constant and continuous renewal of human generations. Since the natural movement of the population is a process analysis of the birth and death of people, this paper considers such types of population reproduction as archetype, traditional type, transitional type and modern type.

For the analysis of the natural movement of the population as a component of demographic safety, the following indicators were evaluated: average life expectancy at birth; depopulation rate; the overall mortality rate of the country's population; infant mortality (child mortality up to the age of 1); total birth rate; net reproduction rate; marriage rate; divorce rate. The findings of the analysis show that the main reason of the worsening of demographic situation is decrease in the birth rate and in-crease in the mortality rate. Currently, the birth rate in Ukraine is largely limited by both economic factors (insufficient wages, shortage of jobs) and social factors (changes in reproductive habits and norms expressed in the popularity of single-parent families). The analysis revealed socio-economic factors influencing the demographic situation in Ukraine.

\section{1. Ветуп}

В сучасних умовах розвитку світу все більшої актуальності набуває впровадження автоматизованих систем, як у виробничі процеси, так і в побутове життя людей. Однак, стрімке впровадження інформаційних технологій в усі сфери життєдіяльності та розвиток штучного інтелекту не виключає необхідність дослідження демографічних змін, а навпаки створюють актуальність корегування демографічних процесів. Це пояснюється тим, що одним 3 найважливіших чинників роз- 
витку країни є iї демографічний стан, тобто якісні та кількісні характеристики населення.

Однак, головне багатство країни - ії людський потенціал, який є основою іiі існування. Роль населення як носія інтелектуального потенціалу значно зростає в постіндустріальних країнах, де саме інтелект нації стає основним рушієм і визначальним чинником прогресу. Будь-яка втрата людських ресурсів незалежно від характеру і конкретних причин як в кількісному, так і в якісному аспектах, стає не лише внутрішньополітичною, але і геополітичною проблемою. Ці втрати дестабілізують і ослабляють країну, стаючи загрозою національній безпеці [2, с. 37].

Демографічний чинник є одним 3 визначальних для забезпечення стабільного й безпечного розвитку країни, а питання демографічного розвитку слід розглядати як фактор і водночас як результат функціонування держави [5].

Отже для забезпечення сталого розвитку держави одним з головних чинників $€$ відтворення інтелектуального потенціалу, тобто населення країни. Також варто підкреслити, що питання аналізу і оцінки демографічної ситуації в Україні залишаються актуальні, оскільки демографічна безпека країни є важливою складовою національної безпеки кожної країни світу.

Мета роботи полягає у виявлені тенденцій зміни основних показників, які характеризують демографічні процеси в країні.

Відповідно до мети дослідження сформовано та вирішено наступні завдання:

вивчення теоретичних засад дослідження демографічної ситуації країни;

визначення індикаторів аналізу природного руху населення;

аналіз чисельності населення України;

проведення оцінки зміни показників відтворення та природного руху населення України;

визначення факторів впливу на зміну чисельності населення України.

Методологічною та інформаційною основою роботи є наукові праці, матеріали періодичних видань, ресурси Internet, нормативно-правові акти та дані Державної служби статистики України та Інституту демографії та соціальних досліджень імені М.В. Птухи.

При проведенні дослідження використано методи структурно-динамічного аналізу, порівняння та узагальнення даних Державної служби 
статистики України та Інституту демографії та соціальних досліджень імені М.В. Птухи.

\section{2. Теоретичні засади дослідження демографічної ситуації країни}

При вивчення будь якого явища або процесу перш за все необхідно визначити категоріальний апарат. Виходячи з мети дослідження доцільно визначити поняття відтворення та природного руху населення.

Під відтворенням населення, в широкому розумінні, слід розглядати історично і соціально-економічно обумовлений процес постійного і безперервного поновлення людських поколінь.

Слід зазначити, що у процесах відтворення населення розрізняють види руху, типи і режими.

Види руху відтворення населення наведено на рис. 1.

Оскільки природний рух населення - аналіз процесів народжуваності і смертності населення, то варто розглянути типи відтворення населення (рис. 2).

В сучасному світі архетип відтворення населення притаманний для деяких племен індіанців Амазонки і Індонезії. Даний тип населення

Природний рух

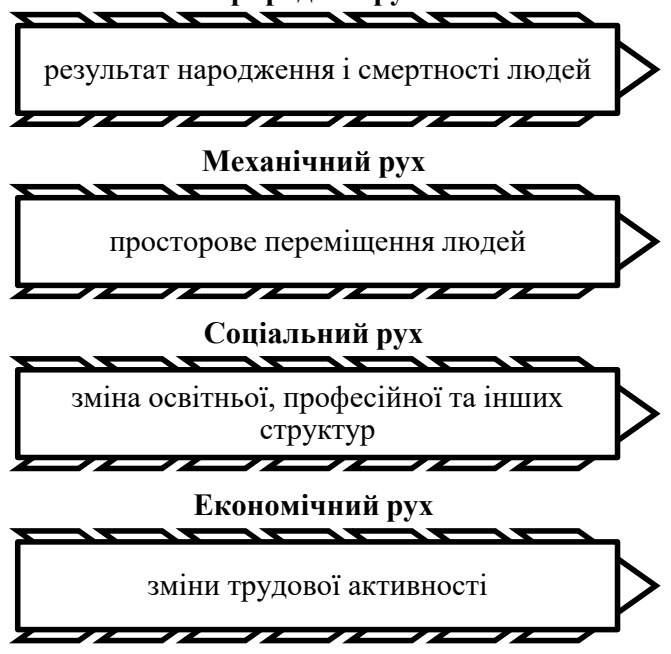

Рис. 1. Види руху відтворення населення 


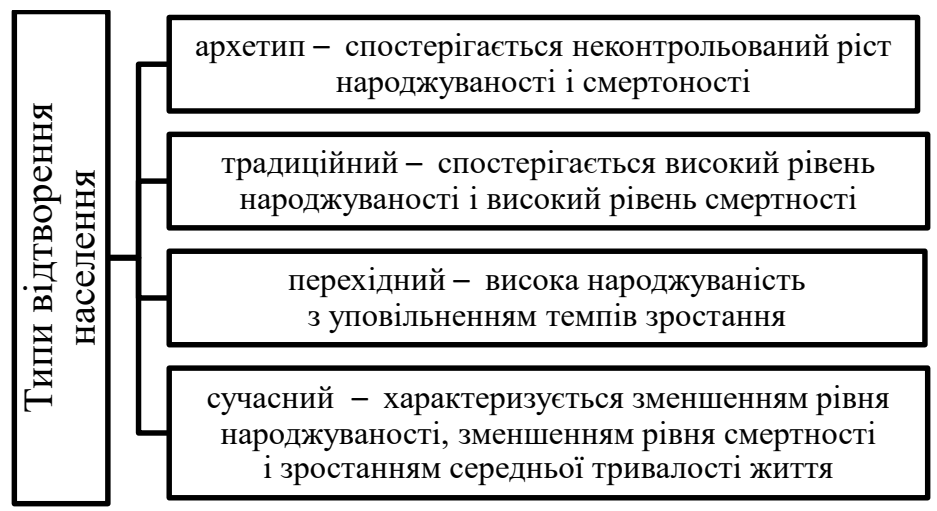

Рис. 2. Типи відтворення населення

спостерігався у первісному суспільстві і характеризувався неконтрольованою народжуваністю та смертністю населення, надзвичайно низькою тривалістю життя (18-25 років), повільним збільшенням населення (період подвоєння населення становить в середньому 250 років).

Традиційний тип відтворення населення притаманний країнам Африки та Азії і характеризується також високим рівнем неконтрольованої народжуваності, при цьому рівень смертності зменшується, однак залишається високим, чисельність населення зростає (період подвоєння населення - 50 років), в суспільстві переважають багатодітні сім'ї. Поліпшення медицини призвело до збільшення тривалості життя (25-45 років).

Сучасний тип відтворення населення виник при переході від аграрної до індустріальної економіки. Даному типу притаманні наступні характеристики: низький рівень народжуваності; середній або навіть низький рівень смертності; низький природний приріст і висока середня тривалість життя.

Цей тип відтворення властивий економічно розвиненим країнам 3 більш високим рівнем життя і культури жителів. Низька народжуваність обумовлена свідомим регулюванням розміру сімей, а низький рівень смертності і висока тривалість життя - успіхами медицини i найкращим рівнем життя.

Перехід від одного типу населення зумовлений історичними процесами розвитку країн і має декілька стадій (табл. 1). 


\section{Стадії демографічного переходу}

\begin{tabular}{|l|l|}
\hline \multicolumn{1}{|c|}{ Стадія демографічного переходу } & \multicolumn{1}{|c|}{ Характеристика стадії } \\
\hline $\begin{array}{l}\text { Висока народжуваність при різкому } \\
\text { скороченні смертності }\end{array}$ & $\begin{array}{l}\text { Дуже високий природний приріст. } \\
\text { Розширене відтворення. }\end{array}$ \\
\hline $\begin{array}{l}\text { Подальше зниження смертності при } \\
\text { більшому зниженні народжуваності } \\
\text { (внаслідок переходу від багатодітної } \\
\text { до малодітної сім’і) }\end{array}$ & $\begin{array}{l}\text { Уповільнення природного приросту. } \\
\text { Розширене відтворення. }\end{array}$ \\
\hline $\begin{array}{l}\text { Деяке підвищення рівня смертності } \\
\text { внаслідок «старіння» населення) при } \\
\text { уповільненому зниженні народжуваності }\end{array}$ & $\begin{array}{l}\text { Слабо розширене відтворення. } \\
\text { Просте відтворення. }\end{array}$ \\
\hline $\begin{array}{l}\text { Показники народжуваності та смертності } \\
\text { вирівнюються }\end{array}$ & $\begin{array}{l}\text { Припинення зростання населення, } \\
\text { спад населення. звужене відтворення }\end{array}$ \\
\hline
\end{tabular}

Виходячи з даних табл. 1, слід зауважити, що існують режими відтворення населення в залежності від кінцевих результатів процесу відновлення поколінь (рис. 3).

При звуженому відтворенні населення загрожує депопуляція систематичне зменшення населення, тобто коли наступні покоління чисельно менші за попередні. Такий режим відтворення населення притаманний Україні за рахунок як природних, так і зовнішніх причин.

Демографічна політика - це цілеспрямована діяльність державних органів і інших соціальних інститутів у сфері регулювання процесів відтворення населення.

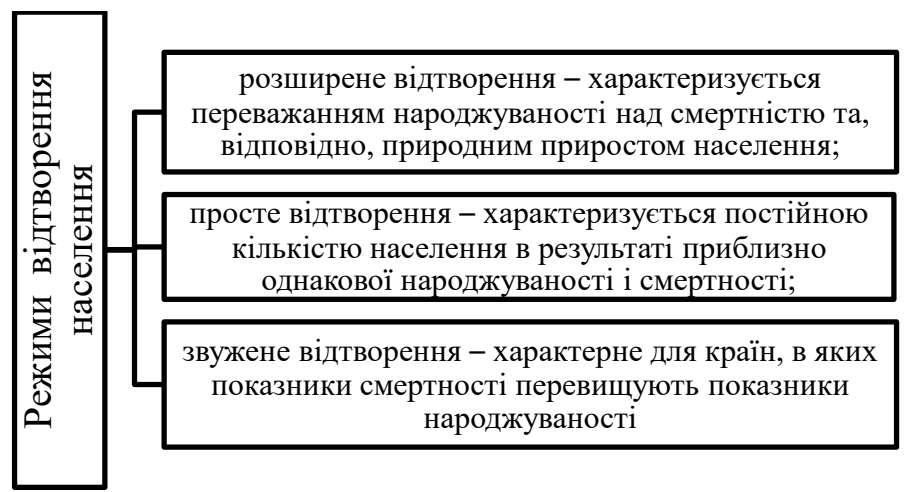

Рис. 3. Режими відтворення населення 
Метою демографічної політики України є поступова стабілізація чисельності населення та формування передумов подальшого демографічного зростання.

Загальне скорочення чисельності населення, зниження його щільності створюють небезпеку ослаблення політичного, економічного та військового впливу України в світі, можливість додаткових домагань на територію України.

Зменшення чисельності молоді, яка вступає в працездатний вік, викликає небезпеку загострення проблеми комплектування збройних сил, правоохоронних органів та інших силових структур, що представляє собою загрозу збереження оборонного потенціалу країни і охорони державних кордонів.

Скорочення чисельності дітей і підлітків призведе до виникнення проблеми формування трудових ресурсів, зменшення обсягів підготовки кваліфікованих кадрів, руйнування самої системи підготовки кадрів, що може створити загрозу технологічній залежності України.

Реальна економічна загроза пов'язана зі зменшенням чисельності працездатного населення і відповідно зі скороченням економічного потенціалу країни. За оцінками західних експертів в цілому в розвинених країнах зниження частки населення працездатного віку може викликати падіння темпів їх економічного розвитку, що в свою чергу призведе до зменшення частки розвинених країн у світовій економіці i, відповідно, зменшення їх впливу в світі.

У зв'язку зі старінням населення виникає небезпека дефіциту робочої сили, збільшення демографічного навантаження на працездатне населення. Також підвищиться навантаження на систему охорони здоров'я, загостряться проблеми з виплатою пенсій і соціальних допомог. Дефіцит робочої сили може покриватися за рахунок нерегульованої імміграції з країн Середнього Сходу, Китаю, В’єтнаму.

Скорочення чисельності окремих етнічних груп може привести до їх повного зникнення.

Відтік з України кваліфікованих працівників веде до послаблення наукового, творчого та економічного потенціалу країни.

Приплив в Україну небажаних груп мігрантів призводить до міжетнічних конфліктів і підвищення криміногенної ситуації в країні. 
Виходячи із вище зазначеного витікає необхідність вивчення та аналізу демографічних процесів в Україні та пошуку невідкладних рішень для іiї стабілізації.

Отже, як відзначалося природний рух населення є складовою демографічної безпеки країни. Для аналіз природного руху населення, як складової демографічної безпеки доцільно розглядати наступні індикатори [1]:

середня очікувана тривалість життя при народженні - найважливіший індикатор демографічної безпеки, підсумковий показник якості життя й соціально-економічних можливостей в країні;

коефіцієнт депопуляції - величина природного приросту населення, тобто перевищення числа померлих над числом народжених;

загальний коефіцієнт смертності населення країни;

смертність немовлят (смертність дітей до 1 року) - показники смертності дітей є принципово важливими демографічними й соціальними індикаторами. Вони віддзеркалюють загальну якість життя населення, інтегруючи результати екологічних, економічних, освітніх, політичних, медичних та інших здобутків чи проблем країни;

сумарний коефіцієнт народжуваності - кількість дітей на одну жінку репродуктивного віку;

неттопоказник відтворення населення на одну жінку характеризує ступінь заміщення покоління матерів поколінням дочок. Якщо він менший за одиницю - кожне наступне покоління матерів менше від попереднього;

коефіцієнт шлюбності показує, скільки шлюбів припадає на 1000 чоловік протягом календарного року;

коефіцієнт розлучуваності показує, скільки розлучень припадає на кожну тисячу населення протягом календарного року.

Даний перелік індикаторів не $є$ абсолютним, перелік показників може бути розширений залежно від мети та глибини дослідження.

\section{3. Статистична оцінка зміни показників відтворення та природного руху населення України}

На даний час Україна входить до 30 найстаріших країн світу за часткою осіб віком від 60 років: у 2015 році така частка становила 21,8\% загальної чисельності населення, а частка осіб віком від 65 років і 
старше - 15,5\% загальної чисельності населення. Згідно 3 національним демографічним прогнозом, на період до 2025 року частка осіб віком понад 60 років становитиме 25\% загальної кількості населення, віком 65 років і старше - 18,4\%, у 2030 році - понад $26 \%$ та понад $20 \%$ відповідно [6]. Невідворотність демографічного старіння вимагає адекватної реакції суспільства на зміни соціально-демографічних умов життєдіяльності населення та наслідки прискореного старіння. Соціально-економічні наслідки демографічного старіння пов'язані насамперед із скороченням чисельності осіб працездатного віку, збільшенням демографічного та економічного, отже, податкового навантаження на осіб працездатного віку, збільшенням попиту на соціальні та медичні послуги серед громадян похилого віку. Старіння населення найбільше впливатиме на публічні фінанси (зокрема, пенсійні кошти), ринок праці, системи охорони здоров'я та соціальних послуг. Прискорене зростання частки громадян похилого віку в загальній кількості населення впливає також на загальну зміну потреб в освітніх, житлово-комунальних і транспортних послугах, на структуру взаємодії на рівні громад [6].

Для аналізу природного руху населення в першу чергу необхідно оцінити чисельність населення в країні, а також проаналізувати кількість економічно активного населення (табл. 2).

Виходячи 3 табл. 2 спостерігається поступове скорочення чисельності населення України та економічно активного населенні у 2000-2019 рр. На скорочення чисельності населення країни впливають природні та зовнішні чинники. До природних чинників відноситься скорочення народжуваності, достатньо високий рівень смертності, до зовнішніх - бойові дії на території України, окупація частини територій країни та ін.

Для аналізу швидкості скорочення населення проаналізуємо темпи зростання чисельності населення та кількості економічно активного населення (рис. 4).

Дані рис. 4 свідчать, що у 2000-2019 рр. щорічно чисельність населення країни скорочувалась в середньому менше ніж на 1\% (на 0,8\%), при цьому щорічне зменшення економічно активного відбувалося майже на 2\%. Дана тенденція свідчить про скорочення населення працездатного віку. 
Чисельність населення України [3]

\begin{tabular}{|c|c|c|}
\hline Роки & $\begin{array}{c}\text { Всього населення, } \\
\text { тис. осіб }\end{array}$ & $\begin{array}{c}\text { Економічно активне } \\
\text { населення, тис. осіб }\end{array}$ \\
\hline 2000 & 48923,2 & 21150,7 \\
\hline 2001 & 48457,1 & 20893,6 \\
\hline 2002 & 48003,5 & 20669,5 \\
\hline 2003 & 47622,4 & 20618,1 \\
\hline 2004 & 47280,8 & 20582,5 \\
\hline 2005 & 46929,5 & 20481,7 \\
\hline 2006 & 46646 & 20545,9 \\
\hline 2007 & 46372,7 & 20606,2 \\
\hline 2008 & 46143,7 & 20675,7 \\
\hline 2009 & 45962,9 & 20321,6 \\
\hline 2010 & 45778,5 & 20220,7 \\
\hline 2011 & 45633,6 & 20247,9 \\
\hline 2012 & 45553 & 20393,5 \\
\hline 2013 & 45426,2 & 20478,2 \\
\hline 2014 & 42928,9 & 19035,2 \\
\hline 2015 & 42760,5 & 17396 \\
\hline 2016 & 42584,5 & 17303,6 \\
\hline 2017 & 42386,4 & 17193,2 \\
\hline 2018 & 42153,2 & 17296,2 \\
\hline 2019 & 41902,4 & 17381,8 \\
\hline & & \\
\hline & & \\
\hline
\end{tabular}

Також, слід відзначити, що у 2014 р. порівняно з 2013 р. відбулося значне скорочення показників, що аналізуються, це пов'язано з подіями на Донбасі та окупацією частиною території України.

Отже, чисельність населення щорічно скорочується під впливом, як природних так і міграційних процесів.

Для більш детального аналізу проаналізуємо демографічне навантаження у динаміці. При цьому під демографічним навантаженням слід розуміти, як узагальнюючу кількісну характеристику вікової структури населення, яка показує навантаження на суспільство непродуктивним населенням (рис. 5). 
Hanna Svydlo, Iryna Sierova

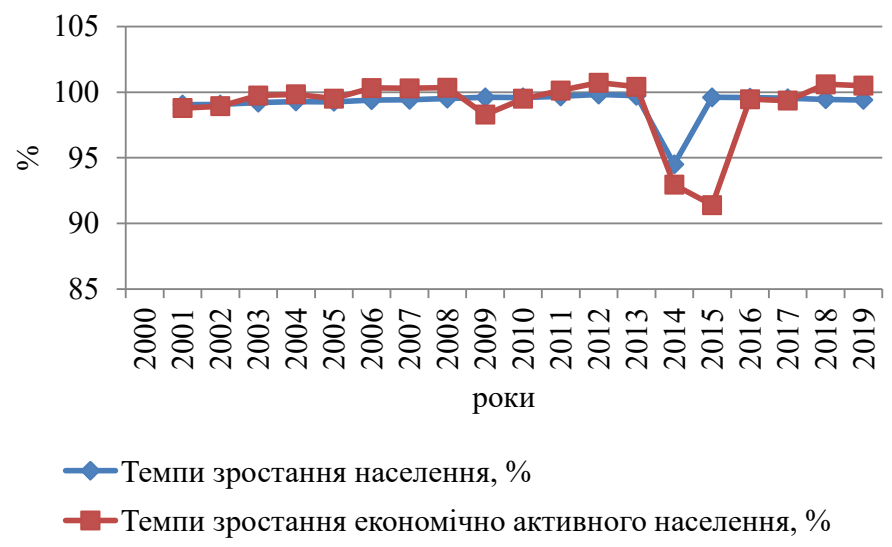

Рис. 4. Темпи зростання чисельності населення та кількості економічно активного населення за 2000-2019 pp. [3]

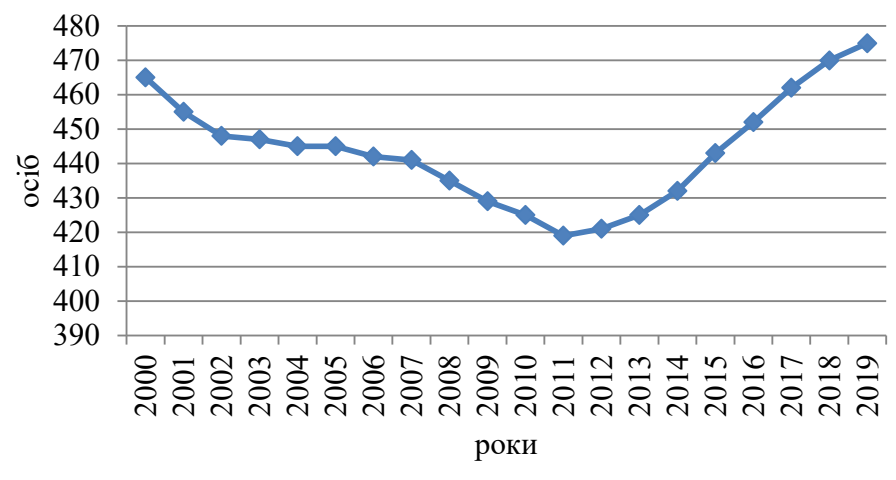

$\neg$-Загальне навантаження

Рис. 5. Загальне навантаження на осіб у віці 15-64 років за 2000-2019 рр. [4]

Навантаження на осіб у віці 15-64 роки, розраховується, як відношення кількості осіб у віці 0-14 років, 65 років і старше до кількості населення у віці 15-64 роки. 
Починаючи 32000 р. загальне навантаження на осіб у віці від 15-64 років поступово зменшувалось, мінімальне навантаження спостерігалось у 2011 р. і складало 419 особу. Однак, в 2012 р. даний показник щорічно в середньому зростає на 1,6\% і в 2019 р. склав 475 осіб, що перевищує показник 2000 р. Дана тенденція свідчить про скорочення економічно активного населення та збільшення частки населення у віці $0-14$ років, 65 років і старше.

Також варто відзначити, що нинішня демографічна ситуація в Україні ускладнюється ще й тим, що молоді люди віком 15-24 років становлять значну частку безробітних, а люди віком 25-40 років мігрують за кордон у пошуках роботи та вищого заробітку. Старіння населення на фоні підвищеної міграції призводить до збільшення фінансового навантаження на систему пенсійного забезпечення. Сьогодні в Україні практично кожна третя особа - пенсіонер, основним показником якості та рівня життя якого є розмір пенсії. Збільшення частки пенсіонерів у загальній чисельності населення неодмінно призводить до зростання економічної вартості надання підтримки цій категорії.

На рис. 6 наведено зміну чисельності населення України за статевою структурою.

Загалом, кількість жінок перевищує кількість чоловіків, проте, як чисельність жінок, так і чисельність чоловіків скорочується. Чисель-

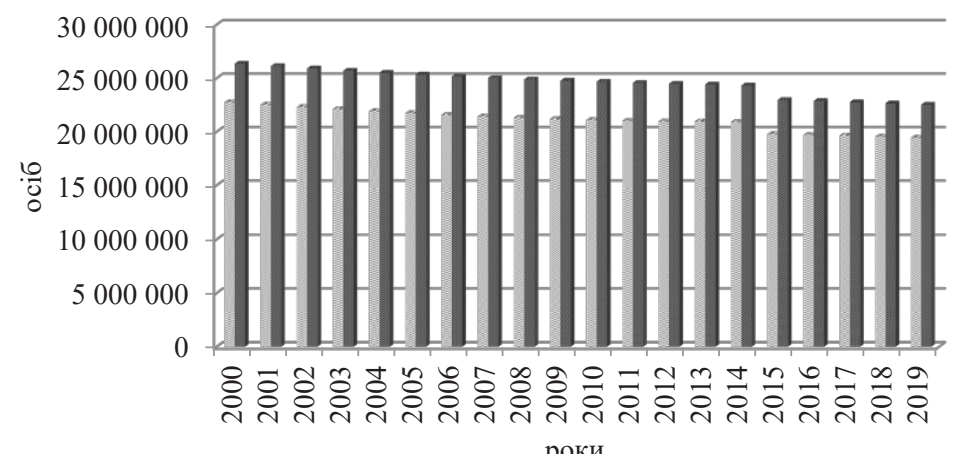

$\approx$ Чисельність чоловіків Чисельність жінок

Рис. 6. Динаміка статевої структури населення за 2000-2019 рр. [4] 
ність чоловіків та жінок у 2019 р. порівняно з 2000 р. скоротилася майже на 15\%. У середньому щорічно за період з 2000-2019 pр. чисельність чоловіків знижується на $0,77 \%$, а чисельність жінок знижується на $0,78 \%$.

В Україні спостерігається гендерна диспропорція, тобто, на тисячу жінок у середньому приходиться 856 чоловіків. Після межі у 32 роки ситуація тільки погіршується, до пенсійного віку в Україні залишається майже на 90 тис. більше жінок, ніж чоловіків. На думку фахівців Інституту демографії кількість чоловіків зменшується і через біологічні і через поведінкові фактори. Смертність чоловіків у працездатному віці більше у 2,5-3 рази, також, чоловіки за своєю природою менш життєздатні, тобто біологічні фактори забирають у них приблизно два роки життя порівняно з жінками. В цілому. Через поведінкові фактори чоловіки у середньому живуть на 10 років менше ніж жінки, адже чоловіки частіше зайняті на шкідливому виробництві, також життя їм скорочує несвідоме ставлення до власного здоров'я та ігнорування порад медиків.

Головними показниками, що відображають процес природного руху населення є смертності, народжуваності та смертність дітей до 1 року.

На рис. 7 подані дані про кількість смертність та народжуваність у 2000-2019 pp.

Аналіз даних рис. 7 дає змогу зробити висновок, що зменшується кількість померлих та народжених. Дана тенденція тісно пов'язана зі

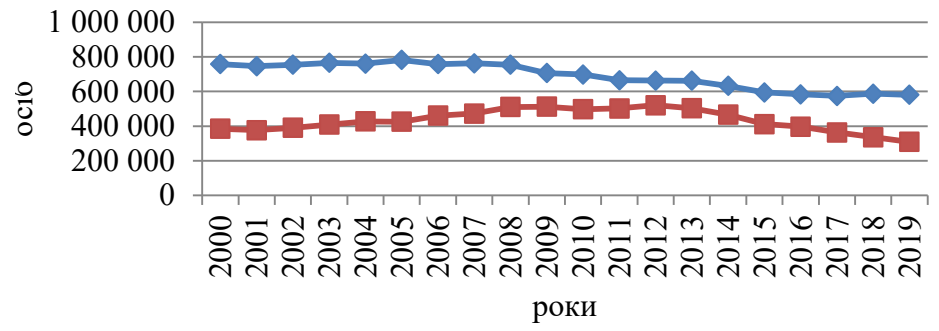

$\leadsto$-Кількість померлих - ㄴ-Кількість живонароджених

Рис. 7. Динаміка кількості померлих та живонароджених осіб у 2000-2019 рp. [4] 
зменшення загальної чисельності населення країни. Однак, варто відзначити, що кількість померлих перевищує чисельність народжених майже в 2 рази.

Можна сказати, що позитивні зміни відбувалися протягом 2010-2012 pр., коли чисельність народжених збільшувалась, а померлих - зменшувалась, однак починаючи з 2013 р. народжуваність поступово зменшується.

Отже, на даний момент головна і найбільш яскрава ознака змін вікової структури населення України - старіння населення, що проявляється в зростанні частки літніх людей і зниженні частки молодих людей. Старіння населення є одним 3 найбільш важливих демографічних процесів, який визначає зміну потреб в освітніх, медичних, соціальних та житлово-комунальних послугах, трансформує трудовий потенціал населення, змінює співвідношення економічно активної і неактивної його частини.

Особливість еволюції вікового складу населення в тому, що при високій смертності дорослих вікова піраміда старіє тільки «знизу» внаслідок зниження народжуваності, на відміну від розвинених країн, де відбувається також старіння «зверху» в результаті зниження смертності.

Для більш детального аналізу в табл. 3 наведено коефіцієнти смертності віковими групами, на 100000 осіб відповідного віку за 2000-2019 рр.

Виходячи 3 даних табл. 3, найбільше значення коефіцієнтів смертності за віковими групами, на 100000 осіб відповідного віку спостерігається у віці 70 і старше. Варто звернути увагу, що у віці від 0 до 4 років в середньому близько 260 осіб на 100000 осіб відповідного віку, однак спостерігається зменшення коефіцієнту смертності починаючи 3 вікової групи від 5 до 9 років (в середньому 20 осіб на 100000 осіб) 3 поступовим збільшенням по кожній віковій групі.

Показники смертності дітей є принципово важливими демографічними й соціальними індикаторами. Вони віддзеркалюють загальну якість життя населення, інтегруючи результати екологічних, економічних, освітніх, політичних, медичних та інших здобутків чи проблем країни (рис. 8).

Кількість смертей дітей до 1 року у 2002-2019 рр. щорічно в середньому зменшується на 3,5\%. Незважаючи на позитивні тенденції в 


\begin{tabular}{|c|c|c|c|c|c|c|c|c|c|c|c|c|c|c|c|c|c|c|}
\hline & 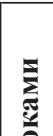 & ஓ્ఠ & $=$ & $\stackrel{\sim}{\sim}$ & $\begin{array}{l}\nabla_{0} \\
\stackrel{\sim}{*}\end{array}$ & $\begin{array}{c}\text { के } \\
\stackrel{\infty}{N}\end{array}$ & $\underset{\vartheta}{\nabla_{0}}$ & $\overrightarrow{\stackrel{ \pm}{ \pm}}$ & $\begin{array}{l}\stackrel{0}{=} \\
\vec{\sim}\end{array}$ & $\begin{array}{l}n \\
\text { ñ } \\
\text { fo }\end{array}$ & $\stackrel{\sim}{\tilde{f}}$ & $\begin{array}{l}\text { No } \\
\infty \\
\text { in }\end{array}$ & $\stackrel{\infty}{\infty}$ & $\stackrel{\tilde{0}}{\underline{\theta}}$ & $\stackrel{a}{a}$ & $\begin{array}{l}0 \\
\hat{\sigma} \\
\text { त. }\end{array}$ & $\stackrel{\substack{n \\
m}}{m}$ & $\begin{array}{l}0 \\
\stackrel{0}{\circ} \\
\stackrel{\infty}{0}\end{array}$ \\
\hline & 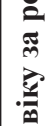 & 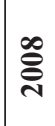 & 으 & $\vec{\nabla}$ & $\hat{\circ}$ & $\vec{\infty}$ & $\stackrel{2}{2}$ & 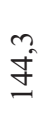 & $\begin{array}{l}\forall \\
\stackrel{\sigma}{\sigma} \\
\stackrel{\sim}{7}\end{array}$ & 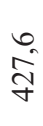 & $\begin{array}{l}n \\
\tilde{n} \\
n\end{array}$ & 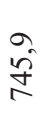 & $\begin{array}{l}0 \\
\text { จे } \\
\text { aे }\end{array}$ & $\begin{array}{l}0 \\
\stackrel{2}{n} \\
\stackrel{n}{n}\end{array}$ & $\frac{n}{\infty}$ & $\stackrel{n}{\tilde{f}}$ & $\begin{array}{l}\text { O } \\
\text { İ } \\
\text { ते }\end{array}$ & $\underset{\infty}{\stackrel{\sim}{=}}$ \\
\hline$\Xi$ & 를 & 옹 & $a$ & $\begin{array}{l}\text { भે } \\
\text { ڤે } \\
\text { Әे }\end{array}$ & 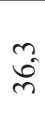 & $\begin{array}{l}0 \\
\text { ñ }\end{array}$ & $\begin{array}{l}\overbrace{+} \\
\text { ஸे }\end{array}$ & $\begin{array}{l}\stackrel{\sim}{\sim} \\
\stackrel{\sim}{n}\end{array}$ & 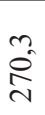 & 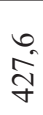 & $\begin{array}{l}{ }_{n} \\
\text { in } \\
\text { n. }\end{array}$ & $\stackrel{\sqrt[n]{n}}{n}$ & $\begin{array}{l}n \\
2 \\
\Omega\end{array}$ & $\underset{\vec{\sigma}}{\vec{\Xi}}$ & $\stackrel{\nabla_{n}}{\stackrel{\Omega}{\Omega}}$ & $\stackrel{\stackrel{n}{\sim}}{\stackrel{\sim}{\sim}}$ & 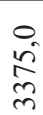 & $\begin{array}{l}\circ \\
\dot{\infty} \\
+ \\
+\end{array}$ \\
\hline 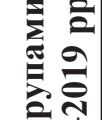 & $\begin{array}{c}\cdot \frac{\pi}{0} \\
\cdot \frac{0}{8} \\
0 \\
0\end{array}$ & ஓ̊ำ & $\infty$ & $\stackrel{n}{\stackrel{n}{2}}$ & $\vec{m}$ & $\stackrel{\infty}{\infty}$ & $\hat{\sigma}$ & $\stackrel{\Im}{\stackrel{f}{ \pm}}$ & 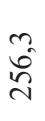 & $\begin{array}{l}0 \\
\infty \\
\infty \\
m\end{array}$ & $\begin{array}{l}\infty \\
\stackrel{\sim}{n}\end{array}$ & $\stackrel{N}{\underset{N}{N}}$ & $\begin{array}{l}0 \\
\stackrel{2}{0} \\
\curvearrowleft\end{array}$ & $\frac{n}{n}$ & $\begin{array}{l}\infty \\
\infty \\
\infty \\
=\end{array}$ & $\stackrel{\infty}{\stackrel{\infty}{+\infty}}$ & $\stackrel{n}{\stackrel{n}{F}}$ & $\begin{array}{l}0 \\
\infty \\
\infty \\
\infty\end{array}$ \\
\hline 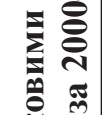 & $\frac{\varrho}{\stackrel{\Xi}{\Xi}}$ & ஜ্ণ & $r$ & $\frac{a}{\hat{N}}$ & $\stackrel{\vec{\infty}}{\hat{m}^{\circ}}$ & $\frac{\infty}{m}$ & $\stackrel{2}{2}$ & $\begin{array}{l}0 \\
\infty \\
\pm \\
\pm\end{array}$ & $\begin{array}{l}\sigma_{0} \\
\text { Dे }\end{array}$ & $\overrightarrow{\mathrm{n}}$ & 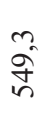 & $\begin{array}{l}0 \\
n \\
n\end{array}$ & $\begin{array}{l}\overrightarrow{0} \\
\text { 으 }\end{array}$ & 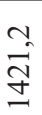 & $\begin{array}{l}\overrightarrow{0} \\
\infty \\
\infty\end{array}$ & $\begin{array}{l}\infty \\
\text { a } \\
\text { do }\end{array}$ & $\frac{\infty}{n}$ & $\underset{\infty}{\sim}$ \\
\hline 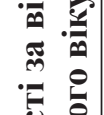 & 音 & ఫ্ণ & 6 & $\overrightarrow{\tilde{J}}$ & $n$ & $\begin{array}{l}\dot{J}_{n} \\
\text { ñ }\end{array}$ & $\overrightarrow{\mathbb{N}}$ & $\stackrel{n}{\text { g }}$ & $\hat{\stackrel{0}{0}}$ & $\frac{m}{N}$ & $\begin{array}{l}n \\
\tilde{n} \\
n\end{array}$ & $\stackrel{\stackrel{\sigma}{ \pm}}{\stackrel{N}{N}}$ & 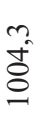 & 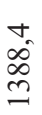 & $\stackrel{2}{\stackrel{2}{2}}$ & $\begin{array}{l}0 \\
\text { iี } \\
\stackrel{2}{n}\end{array}$ & $\begin{array}{l}+ \\
\stackrel{+}{n} \\
\stackrel{n}{n}\end{array}$ & $\begin{array}{l}a \\
\frac{0}{n} \\
\frac{\infty}{\infty}\end{array}$ \\
\hline 를 & 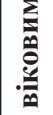 & ๙̊ఠ్ & in & $\begin{array}{l}\hat{b} \\
\text { ते }\end{array}$ & $\stackrel{a}{n}$ & $\stackrel{\Rightarrow}{m}$ & $\hat{\infty}$ & $\begin{array}{l}n \\
\infty \\
n\end{array}$ & \begin{tabular}{l}
0 \\
\multirow{n}{n}{} \\
ñ
\end{tabular} & $\frac{n}{n}$ & ๙ે & $\frac{\nabla_{0}}{\sigma}$ & ก̃ & $\begin{array}{l}n \\
\text { ñ } \\
\end{array}$ & 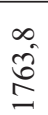 & $\begin{array}{l}0 \\
\tilde{n} \\
\tilde{n} \\
\tilde{n}\end{array}$ & $\begin{array}{l}0 \\
0 \\
\stackrel{0}{0} \\
\text { m }\end{array}$ & $\begin{array}{l}\infty \\
\stackrel{\infty}{\infty}\end{array}$ \\
\hline 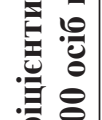 & 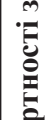 & ฮิ & $\nabla$ & $\begin{array}{l}0 \\
\infty \\
\infty \\
\infty \\
\sim\end{array}$ & $\begin{array}{c}m \\
\infty \\
m\end{array}$ & $n$ & $\begin{array}{l}\sigma_{0} \\
\text { i }\end{array}$ & $\begin{array}{l}\stackrel{0}{n} \\
\cong\end{array}$ & $\begin{array}{l}\infty \\
\text { in } \\
\text { ñ }\end{array}$ & $\stackrel{\tilde{n}}{\stackrel{n}{n}}$ & $\frac{\sim}{\gamma}$ & $\stackrel{\sigma}{\sigma}$ & ๙̃ & $\begin{array}{l}\vec{b} \\
\stackrel{2}{n} \\
\stackrel{n}{n}\end{array}$ & \begin{tabular}{l}
\multirow{2}{\Omega}{} \\
$\stackrel{2}{I}$
\end{tabular} & 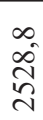 & $\underset{\sim}{\stackrel{N}{N}}$ & $\begin{array}{l}0 \\
\tilde{n} \\
\stackrel{n}{\infty}\end{array}$ \\
\hline 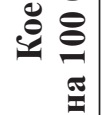 & 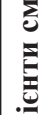 & 흉 & $m$ & $\hat{\tilde{N}}$ & $\hat{m}$ & $\stackrel{m}{n}$ & $\begin{array}{l}\nabla_{0} \\
\stackrel{\infty}{ }\end{array}$ & $\stackrel{0}{\Omega}$ & $\vec{n}$ & $\begin{array}{l}n \\
\text { o } \\
\text { m }\end{array}$ & 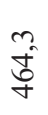 & \begin{tabular}{l} 
N \\
\multirow{J}{*}{}
\end{tabular} & $\frac{a}{n}$ & $\begin{array}{l}\text { ్ֶ } \\
\infty \\
\text { }\end{array}$ & $\begin{array}{l}\vec{\infty} \\
\text { I }\end{array}$ & 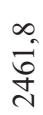 & $\underset{⿱ 乛}{\stackrel{\infty}{+}}$ & $\frac{n}{n}$ \\
\hline & ثِّ & ఫ్ & $\sim$ & $\stackrel{\circ}{\stackrel{\text { ते }}{2}}$ & $\stackrel{n}{n}$ & $\begin{array}{l}\sim \\
\infty \\
\infty\end{array}$ & $\frac{\sigma_{0}}{\sigma}$ & $\begin{array}{l}\infty \\
\infty \\
\infty\end{array}$ & $\begin{array}{l}\text { Z } \\
\text { J }\end{array}$ & 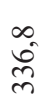 & $\vec{~}$ & ๙ู & $\stackrel{\vartheta}{\check{g}}$ & 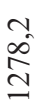 & $\stackrel{n}{\infty}$ & $\stackrel{\text { ले }}{\stackrel{\infty}{\sim}}$ & $\begin{array}{l}0 \\
\text { ñ } \\
\text { ñ } \\
\text { m }\end{array}$ & 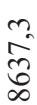 \\
\hline & 前 & 吾 & - & I্ & ì & 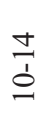 & $\begin{array}{l}\stackrel{a}{\prime} \\
\stackrel{1}{n}\end{array}$ & 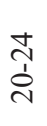 & $\begin{array}{l}\text { ते } \\
\text { ஸे }\end{array}$ & 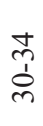 & ભ̂े & ষ্ঠি & 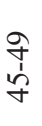 & \begin{tabular}{l}
\multirow{2}{n}{} \\
în \\
in
\end{tabular} & 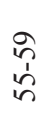 & $\begin{array}{l}\text { J } \\
1 \\
\text { రి }\end{array}$ & $\begin{array}{l}\hat{b} \\
1 \\
6 \\
6\end{array}$ & 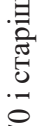 \\
\hline
\end{tabular}




\begin{tabular}{|c|c|c|c|c|c|c|c|c|c|c|c|c|c|c|c|c|}
\hline \multirow{2}{*}{\multicolumn{2}{|c|}{ 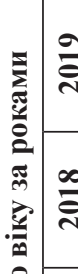 }} & $\begin{array}{l}\text { ठे } \\
\text { ปे }\end{array}$ & $\vec{\infty}$ & $\stackrel{n}{\tilde{N}}$ & $\hat{\sigma}$ & $\stackrel{\sim}{\infty}$ & $\begin{array}{l}\dot{J}^{\prime} \\
\stackrel{\overbrace{}}{=}\end{array}$ & $\frac{n}{\tilde{n}}$ & $\underset{n}{n}$ & $\begin{array}{l}m \\
\tilde{n} \\
\tilde{n}\end{array}$ & $\begin{array}{l}\nabla^{2} \\
\tilde{\sigma}^{\infty}\end{array}$ & ๙̊ & $\frac{a}{\dot{m}}$ & $\begin{array}{l}\nabla_{\alpha} \\
\stackrel{\sim}{\sigma}\end{array}$ & $\begin{array}{l}\stackrel{\sigma}{\sim} \\
\stackrel{\infty}{\sim}\end{array}$ & \begin{tabular}{l}
$n$ \\
\multirow{n}{n}{} \\
$\infty$
\end{tabular} \\
\hline & & ஜூ & $\stackrel{\circ}{\infty}$ & $\frac{a}{\lambda}$ & $\stackrel{\infty}{i}$ & $\begin{array}{l}0 \\
\infty \\
\infty\end{array}$ & 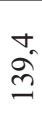 & ते & $\stackrel{\bar{n}}{\bar{m}}$ & $\stackrel{n}{\infty}$ & $\stackrel{n}{\tilde{m}}$ & ๙ે & $\begin{array}{l}\stackrel{0}{+} \\
\stackrel{+}{N}\end{array}$ & $\begin{array}{l}m \\
\infty \\
\infty\end{array}$ & $\frac{\hat{\sigma}}{\stackrel{+}{*}}$ & $\overrightarrow{\text { ๙े }}$ \\
\hline 产 & 를 & $\sqrt{6}$ & $\stackrel{0}{\infty}$ & $\frac{a}{\sim}$ & $\begin{array}{l}\vec{\infty} \\
i^{n}\end{array}$ & $\hat{\infty}$ & $\stackrel{\sim}{\stackrel{\sim}{\sim}}$ & $\begin{array}{l}n \\
\tilde{N} \\
\tilde{N}\end{array}$ & $\begin{array}{l}\infty \\
0 \\
0 \\
0 \\
\infty\end{array}$ & $\hat{\sigma}$ & 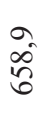 & $\vec{a}$ & $\begin{array}{l}0 \\
\stackrel{0}{\circ} \\
\stackrel{\text { In }}{0}\end{array}$ & $\begin{array}{l}\infty \\
\infty \\
\stackrel{\infty}{0}\end{array}$ & $\begin{array}{l}\vec{\sim} \\
\text { तె } \\
\text { ते }\end{array}$ & $\begin{array}{l}\text { aे } \\
\text { हి } \\
\infty\end{array}$ \\
\hline ํㅜㅇ & 를 & $\stackrel{\vec{\infty}}{\tilde{\infty}}$ & $\stackrel{\Omega}{a}$ & $\begin{array}{c}n \\
\sim\end{array}$ & $\frac{7}{6}$ & $\vec{\infty}$ & กี & $\begin{array}{l}\stackrel{\sigma}{+} \\
\stackrel{+}{2}\end{array}$ & $\hat{n}$ & $\hat{\bar{a}}$ & బ) & $\stackrel{-}{\widehat{N}}$ & $\begin{array}{l}\text { ñ } \\
\stackrel{2}{n}\end{array}$ & $\frac{\infty}{i}$ & $\begin{array}{l}\text { an } \\
\hat{\sigma}_{\infty}\end{array}$ & 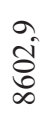 \\
\hline$\frac{\mathscr{O}}{\underset{\sigma}{\sigma}}$ & $\stackrel{n}{\stackrel{\sim}{*}}$ & Nૂ & 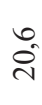 & $\stackrel{\sim}{\stackrel{N}{\sim}}$ & $\begin{array}{l}\infty \\
\pi\end{array}$ & $\stackrel{2}{2}$ & న & 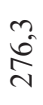 & बूे & $\begin{array}{l}\hat{\gamma} \\
\hat{\delta}\end{array}$ & $\begin{array}{l}0 \\
6 \\
6\end{array}$ & ๙2 & $\begin{array}{l}\nabla_{n} \\
\stackrel{\sim}{\sim} \\
\stackrel{m}{*}\end{array}$ & 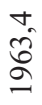 & 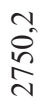 & $\frac{n}{2}$ \\
\hline 离 & $\stackrel{\text { లై }}{\overrightarrow{7}}$ & $\begin{array}{l}n \\
\infty \\
\infty\end{array}$ & $\stackrel{\infty}{-}$ & $\vec{d}$ & $\begin{array}{l}n \\
\infty \\
\infty\end{array}$ & $\begin{array}{l}0 \\
\text { å }\end{array}$ & $\overrightarrow{6}$ & $\vec{\nabla}$ & $\stackrel{\vec{\sigma}}{\vec{\sigma}}$ & $\hat{\sigma}$ & $\stackrel{\overrightarrow{0}}{\overrightarrow{0}}$ & $\begin{array}{l}0 \\
0 \\
\curvearrowleft \\
\curvearrowleft\end{array}$ & $\begin{array}{l}m \\
n \\
n \\
m\end{array}$ & 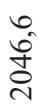 & 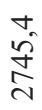 & $\begin{array}{l}\overrightarrow{0} \\
\infty \\
\infty \\
\infty\end{array}$ \\
\hline . & 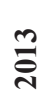 & $\begin{array}{l}0 \\
\text { Oे } \\
\text { ते }\end{array}$ & $\vec{d}$ & $\vec{\sim}$ & 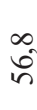 & ฉ̊ & ?2 & $\begin{array}{l}\infty \\
\underset{\sim}{\infty}\end{array}$ & $\begin{array}{l}n \\
\infty \\
n\end{array}$ & $\begin{array}{l}\dot{t}_{n} \\
\stackrel{0}{\circ} \\
\dot{n}\end{array}$ & $\begin{array}{l}0 \\
\frac{\infty}{6}\end{array}$ & $\overrightarrow{\infty^{\circ}}$ & $\begin{array}{l}\text { m} \\
\infty \\
m\end{array}$ & $\frac{\mathfrak{d}}{\stackrel{d}{\delta}}$ & $\begin{array}{l}\vec{a} \\
\vec{d} \\
\stackrel{\sim}{d}\end{array}$ & $\frac{\stackrel{N}{2}}{\stackrel{N}{*}}$ \\
\hline $\begin{array}{l}0 \\
\end{array}$ & 류 & $\frac{m}{2}$ & $\stackrel{\vec{d}}{\sim}$ & $\bar{N}$ & จิ & $\begin{array}{l}\infty \\
0 \\
0\end{array}$ & $\sqrt[n]{6}$ & $\begin{array}{l}\hat{\jmath} \\
\infty \\
\text { ৩ }\end{array}$ & $\begin{array}{l}0 \\
\text { ᄋ } \\
\text { m }\end{array}$ & $\stackrel{\circ}{\stackrel{\alpha}{f}}$ & $\begin{array}{l}0 \\
\frac{1}{6} \\
0\end{array}$ & $\vec{n}$ & 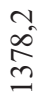 & $\begin{array}{l}0 \\
\text { ஸे } \\
\text { ֻे }\end{array}$ & 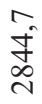 & 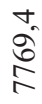 \\
\hline U. & $\overline{\vec{D}}$ & 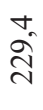 & $\stackrel{\vec{\sim}}{\stackrel{\sim}{*}}$ & $\stackrel{a}{\sim}$ & ڤె & $\stackrel{\sqrt{ \pm}}{\Xi}$ & $\begin{array}{l}\infty \\
\infty \\
\infty\end{array}$ & $\frac{\overrightarrow{0}}{m}$ & \begin{tabular}{l}
0 \\
\multirow{+}{0}{}
\end{tabular} & $\begin{array}{l}\sigma^{2} \\
\tilde{n} \\
\hat{n}\end{array}$ & $\vec{\rho}$ & $\begin{array}{l}\nabla_{n} \\
\text { ă }\end{array}$ & $\begin{array}{l}\text { ? } \\
\text { I } \\
\stackrel{+}{ \pm}\end{array}$ & $\begin{array}{l}\hat{0} \\
\stackrel{0}{\circ}\end{array}$ & $\begin{array}{l}\nabla \\
\text { D } \\
\text { D }\end{array}$ & $\begin{array}{l}\text { ?n } \\
\stackrel{0}{\infty}\end{array}$ \\
\hline 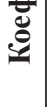 & 을 & $\stackrel{\sqrt{\sim}}{\stackrel{\sim}{\sim}}$ & $\begin{array}{l}{ }_{0} \\
\stackrel{\sim}{n}\end{array}$ & $\begin{array}{l}\text { ñ } \\
\stackrel{\sim}{N}\end{array}$ & तु & $\vec{d}$ & $\begin{array}{l}0 \\
\approx \\
\approx\end{array}$ & $\begin{array}{l}n \\
\text { no } \\
\text { m }\end{array}$ & $\stackrel{\sim}{\mathcal{J}}$ & $\begin{array}{l}n \\
\infty \\
\infty \\
\text { in }\end{array}$ & 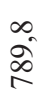 & 亏0 & $\begin{array}{l}\tilde{a} \\
\tilde{D}\end{array}$ & $\begin{array}{l}0 \\
\hat{\sigma} \\
\frac{\pi}{N}\end{array}$ & $\begin{array}{l}0 \\
m \\
m\end{array}$ & $\begin{array}{l}0 \\
\stackrel{0}{8} \\
\stackrel{8}{8}\end{array}$ \\
\hline $\begin{array}{l}\overline{0} \\
\overline{0} \\
0\end{array}$ & 글 & $\stackrel{+}{0}$ & in & $\frac{ \pm}{\grave{b}}$ & $\stackrel{2}{\stackrel{1}{n}}$ & 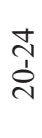 & $\begin{array}{l}\text { ָे } \\
\stackrel{2}{2}\end{array}$ & $\stackrel{+}{\stackrel{+}{1}}$ & $\begin{array}{l}\hat{m} \\
\hat{n} \\
\hat{m}\end{array}$ & $\begin{array}{l}\text { \& } \\
\text { 巳 }\end{array}$ & $\begin{array}{l}\stackrel{9}{+} \\
\stackrel{2}{+}\end{array}$ & $\begin{array}{l}\text { H } \\
\stackrel{n}{n} \\
\stackrel{n}{n}\end{array}$ & $\begin{array}{l}n \\
n \\
n \\
n\end{array}$ & $\begin{array}{l}\text { రి } \\
\text { రి }\end{array}$ & $\begin{array}{l}\hat{b} \\
1 \\
\hat{6}\end{array}$ & 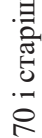 \\
\hline
\end{tabular}




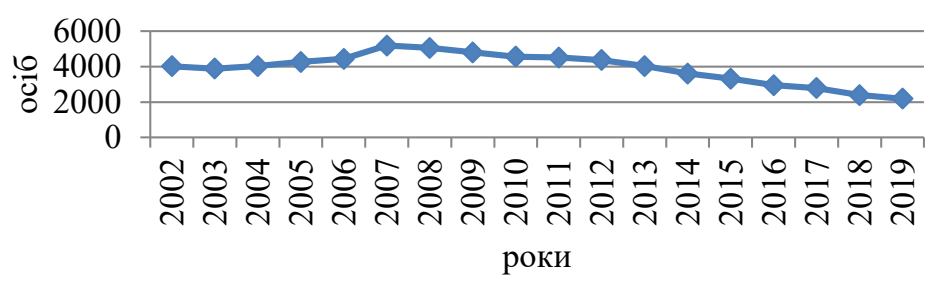

— —ількість смертей дітей у віці до 1 року

\section{Рис. 8. Динаміка кількості смертей дітей у віці до 1 року [4]}

Україні, порівняно з європейськими країнами рівень дитячої смертності ще високий - майже вісім смертей на тисячу народжених живими в Україні, проти 3,76 у Європейському Союзі [1].

Одним 3 важливих демографічних показників $є$ сумарний коефіцієнт на-роджуваності, або рівень фертильності - показник, що відображає гіпотетичну кількість народжень у однієї жінки за все іiі життя за умов збереження існуючих рівнів народжуваності у кожному віці незалежно від смертності та змін вікового складу. Для простого заміщення поколінь сумарний коефіцієнт народжуваності має бути не нижчим за 2,15-2,33, тобто в ідеалі дві третини жінок фертильного віку мали б народити 2 дитини, щоб замінити батьків, а ще третина - трьох дітей, щоб компенсувати більшу ймовірність народити хлопчика і ранньої смерті жінки до закінчення віку, коли вона може народити дитину. Якщо сумарний коефіцієнт народжуваності нижчий, кожне нове покоління стає менш чисельним, ніж попереднє (рис. 9).

Сумарний коефіцієнт народжуваності з 2000 по 2012 рр. поступово збільшувався, однак його значення не перевищувало 1,5. Оскільки сумарний коефіцієнт народжуваності показує скільки в середньому дітей народила б одна жінка упродовж усього репродуктивного періоду (15-49 років) при збереженні в кожному віці рівня народжуваності того року, для якого обчислені вікові коефіцієнти, то в Україні жінка народжує одну дитину за своє життя, чого не достатньо для заміщення поколінь в країні.

Також, важливим показником відтворення населення є нетто-показник відтворення населення, який характеризує кількість дівчат, які 


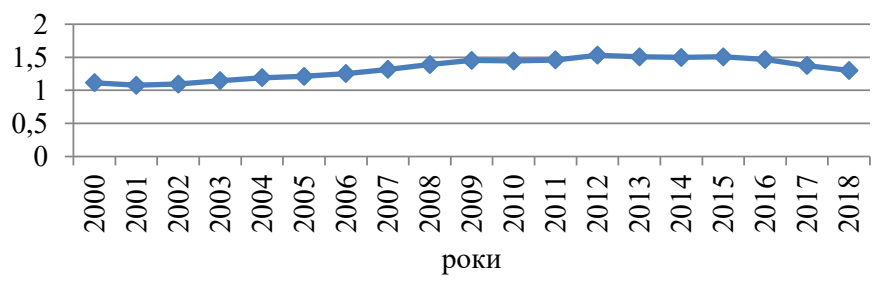

—-Сумарний коефіцієнт народжуваності (на 1 жінку)

Рис. 9. Сумарний коефіціснт народжуваності за 2000-2018 рр. [4]

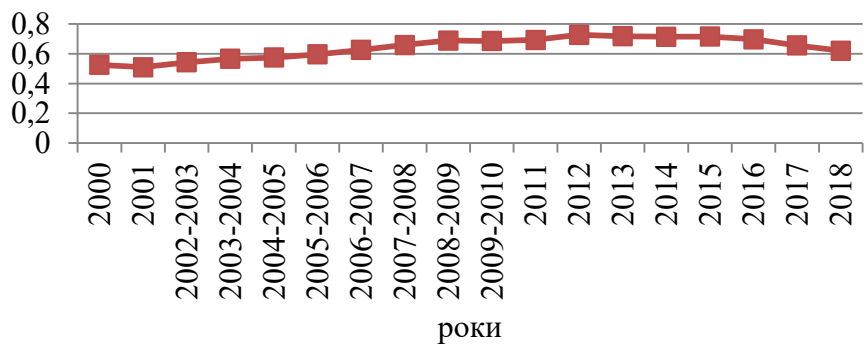

—-Нетто-показник відтворення населення (на 1 жінку)

Рис. 10. Нетто-показник відтворення населення у 2000-2018 рр. [4]

доживуть до віку матері в момент їх народження, з урахуванням функцій народжуваності та смертності жіночого покоління (рис. 10).

Нетто-показник відтворення населення на одну жінку характеризує ступінь заміщення покоління матерів поколінням дочок. Якщо він менший за одиницю - кожне наступне покоління матерів менше від попереднього. В Україні цей індикатор за 2000-2018 рр. ніколи не піднімався вище 0,73 , а за останні три роки досяг критичного значення: 0,656 у 2017 та 0,62 у 2018 р. Статистичні дані ООН для 10 економічно розвинених країн для цього індикатора за періоди 2010-2015 та 2015-2020 свідчать про фактичне звужене відтворення як загальну тенденцію [1].

В сучасних умовах розвитку суспільства можна сказати, що показники шлюбності та розлучуваності опосередковано впливають на відтворення населення. 


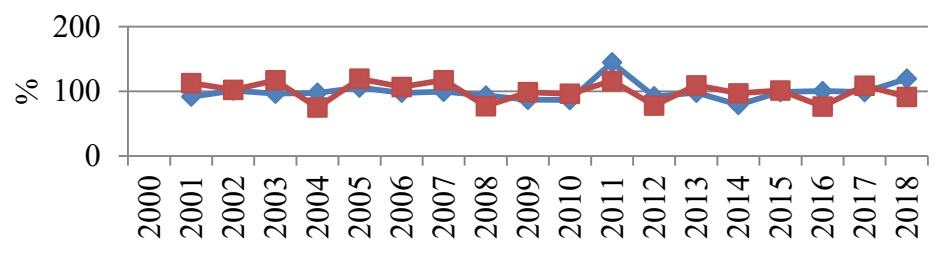

роки

-

- Темпи зростання зареєстрованих шлюбів

Рис. 11. Темпи зростання кількості розірваних шлюбів та заресстрованих шлюбів до попереднього розу за 2000-2018 рр. [4]

На рис. 11 наведено інформацію щодо зміни кількості зареєстрованих шлюбів та числа розірвання шлюбів у 2000-2018 pp.

Виходячи 3 даних рис. 11 спостерігається неоднозначна тенденція показників, що вивчаються. Перш за все, слід зауважити, що щорічно в середньому за 2000-2018 рр. кількість розірваних шлюбів та зареєстрованих шлюбів знижується на 1,3\% та 1\%. Однак, у 2018 р. порівняно з 2017 р. кількість розірваних шлюбів збільшилася на 20\%, при цьому кількість зареєстрованих шлюбів скоротилася на 8,5\%. Отже, похитніть інституту шлюбності також негативно впливає на відтворення населення в Україні.

\section{4. Висновок}

В результаті оцінки індикаторів природного руху населення країни було отримано, що з кожним роком чисельність населення України поступово скорочується за рахунок як природних факторів (народжуваність, смертність) так і за рахунок міграційних процесів. Також, варто відзначити, хоч смертність перевищую народжуваність, однак, щорічно знижується показник смертності немовлят (діти до року), що обумовлено покрашенням медицини. При цьому, відзначається негативна тенденція сумарного коефіцієнту народжуваності. В Україні одна жінка народжує в середньому одну дитину, чого недостатньо для заміщення поколінь. Аналіз показників шлюбності та розлучуваності, також опосередковано впливає на показник природного руху 
населення і похитніть інституту шлюбу має негативний вплив на процеси відтворення населення. Таким чином, основною причиною погіршення демографічної ситуації $є$ зниження рівня народжуваності і збільшення рівня смертності. Сьогодні народжуваність в Україні значною мірою обмежується як факторами економічного порядку (недостатня заробітна плата, недостатня кількість робочих місць), так і соціального (зміна репродуктивних устав та норм, що виражається у масовому розповсюджені однодітних сімей). Також на демографічну ситуацію в країні впливають такі соціально-економічні чинники: затяжна економічна криза в державі, що призводить до зменшення реальної купівельної спроможності населення країни; неефективність використання паливно-енергетичних ресурсів; «тінізація» та криміналізація економіки країни; неефективність державної політики щодо підвищення трудових доходів громадян, подолання бідності та збалансування продуктивної зайнятості працездатного населення; кризовий стан у системі охорони здоров'я і соціальному захисті населення i, як наслідок, небезпечне погіршення стану здоров'я населення; поширення наркоманії, алкоголізму, соціальних хвороб; зменшення можливостей здобуття якісної освіти представниками бідних прошарків суспільства; значне антропогенне порушення і техногенна перевантаженість території України, зростання ризиків виникнення надзвичайних ситуацій техногенного та природного характерів;погіршення екологічного стану. Отже, для вирішення вище зазначених загроз та підвищення рівня народжуваності в країні повинне відбутися впровадження державної програми соціально-економічного зростання, що дозволить підвищити рівень економічного зростання, а це в свою чергу, забезпечить соціальні гарантії населенню, а для зниження рівня смертності необхідно покращити медичне обслуговування, покращити загальну економічну ситуацію в країні та збільшити реальний дохід населення.

Подальше дослідження буде спрямовано на вивчення міграційного руху населення та оцінки ступеня впливу його на зміну чисельності населення України. Планується провести комплексний аналіз зміни чисельності населення України за рахунок природного та міграційного руху населення з визначенням заходів, які будуть сприяти поліпшенню демографічної ситуації в Україні. 


\section{Список літератури:}

1. Грішнова О.А., Харазішвілі Ю.М. Демографічна безпека України: індикатори, рівень, загрози. Demography and Social Economy. 2019. № 2(36). С. 65-80.

2. Римашевская Н.М. Человеческий потенциал и угрозы национальной безопасности. Власть. 2000. № 10. С. 37-45.

3. Сайт Державна служба статистики України. URL: http://www.ukrstat.gov.ua/ (дата звернення: 15.09.2020).

4. Сайт Державна служба статистики України. Інститут демографії та соціальних досліджень імені М.В. Птухи Національної академії наук України. URL: http://database.ukrcensus.gov.ua/MULT/Dialog/statfile1_m.asp (дата звернення: 15.09.2020).

5. Селіванов В. Національна безпека України та іiі забезпечення (концептуальний підхід). Право України. 1992. № 7. С. 9.

6. Стратегія державної політики 3 питань здорового та активного довголіття населення на період до 2022 року. URL: https://zakon.rada.gov.ua/ laws/show/10-2018-\%D1\%80 (дата звернення: 06.09.2020).

\section{References:}

1. Hrishnova O.A., Kharazishvili Yu.M. (2019). Demohrafichna bezpeka Ukrayiny: indykatory, riven', zahrozy [Demographic security of Ukraine: indicators, level, threats]. Demography and Social Economy, no. 2(36), pp. 65-80. (in Ukrainian)

2. Rymashevskaya N.M. (2000). Chelovecheskyy potentsyal y uhrozy natsyonal'noy bezopasnosty [Human potential and threats to national security]. Power, no. 10 , pp. 37-45. (in Ukrainian)

3. Sayt Derzhavna sluzhba statystyky Ukrainy. Retrieved from: http://www.ukrstat.gov.ua/ (accessed: 15.09.2020).

4. Sayt Derzhavna sluzhba statystyky Ukrainy. Instytut demohrafiyi ta sotsial'nykh doslidzhen' imeni M.V. Ptukhy Natsional'noyi akademiyi nauk Ukrayiny. Retrieved from: http://database.ukrcensus.gov.ua/MULT/Dialog/statfile1_m.asp (accessed 15.09.2020).

5. Selivanov V. (1992) Natsional'na bezpeka Ukrayiny ta yiyi zabezpechennya (kontseptual'nyy pidkhid) [National security of Ukraine and its provision (conceptual approach)]. Law of Ukraine, no. 7, p. 9. (in Ukrainian)

6. Stratehiya derzhavnoyi polityky z pytan' zdorovoho ta aktyvnoho dovholittya naselennya na period do 2022 roku [Strategy of state policy on healthy and active longevity of the population until 2022]. Retrieved from: https://zakon.rada.gov.ua/ laws/show/10-2018-\%D1\%80 (accessed 06.09.2020). 